\title{
Economic Value and Historical Scenic Beauty: The Case of Chinampas (Raised Beds) in Xochimilco, UNESCO World Heritage Site, Mexico
}

\author{
Daniel A. Revollo-Fernández \\ Becario del Programa de Becas Posdoctorales en la UNAM, Centro Regional de Investigaciones \\ Multidisciplinarias, UNAM, Campus Morelos de la Universidad Nacional Autonoma de Mexico (UNAM), \\ Cuernavaca, Mexico \\ Email: drevollofer@gmail.com, dalfredo@correo.crim.unam.mx
}

Received 8 February 2015; accepted 20 April 2015; published 22 April 2015

Copyright (C) 2015 by author and Scientific Research Publishing Inc.

This work is licensed under the Creative Commons Attribution International License (CC BY). http://creativecommons.org/licenses/by/4.0/

(c) (i) Open Access

\begin{abstract}
This article estimates the historical scenic beauty's economic value that tourists do have to preserve a pre-Hispanic farm production system dating from XIV to XVI century to be known as chinampas (raised beds) and is located in Mexico City. Therefore, in order to do this, surveys are performed and by contingent valuation (CV), the willingness-to-pay (WTP) is estimated. The best estimation points out that tourists are willing to pay 24.4 dollars around each year, and by means of such estimation, it is estimated that the cultural service's economic value to preserve raised beds is between US\$ 3000 and US\$ 3700 per hectare. Such found value must be used as another input for decision makers when dealing with projects and/or policies facing contrary purposes. The analysis is innovative in the sense that there is almost no CV literature to estimate the economic value of historical scenic beauty.
\end{abstract}

\section{Keywords}

Contingent Valuation, Historical Scenic Beauty, Urban Wetland, Chinampas, UNESCO World Heritage Site

\section{Introduction}

The Ramsar Convention describes international-relevance wetlands as "those marshlands, swamps and peat lands’ extensions, or water-covered surfaces, either natural or artificial, permanent or temporary, blocked or cur- 
rent, fresh or salty, including sea water's extensions which deepness in low tide does not surpass six meters” and meeting also some criteria to be marked within two large groups: 1) sites including representative wetlands types, either strange or unique; and 2) international-relevance sites to preserve biodiversity [1]. When being included in the list of Ramsar sites, governments have the obligation to both preserve ecological and/or cultural features of their wetlands, and plan the rational or sustainable use of these wetlands by means of local and national actions, due to international cooperation as a worldwide sustainable development achievement's contribution [1].

Wetlands are described as very important ecosystems since they provide a huge amount of goods (such as fishing, wood, edible plants, medicines, etc.) and environment services (such as flooding control, carbon collection, water bodies directed nutrient provision, wild species and commercial-interest species housing, water filtration and cleanliness, bird and wild life appreciation, rambling, aesthetical value, etc.) of great value for society [2]-[6]. However, despite offering such environment goods and services to society, worldwide wetlands reduction is increasing [7]. According to Barbier [8], since 1900, more than a half of world wetlands have already disappeared, and this is mainly because of: 1) production of most of the goods and services at the wetlands are public and/or have no properly established property rights [9] [10]; 2) decision makers or users who have no full knowledge of wetlands' economic values commonly [11]; and 3) failures on political interventions or public and/or private projects [7]. As for the United States, it is estimated that $54 \%$ of the wetlands has already disappeared due to farm and urban development mainly [11] [12]. It is a similar situation in Mexico, where according to Landgrave and Moreno-Casasola [13], loss of wetlands reached $62.1 \%$.

An efficient and effective management of wetlands control requires both data about environment goods and services exploitation rate to be offered [14] and their economic information [7] [12] [15]. Information about economic value provides supplies to both authorities and goods and services users, so that policies and/or projects to be developed can reflect their true value [16]-[18]. The aspect is that some environment goods and services, such as food provision or wood extraction, may be economically estimated from their market value. However, not all the goods and services are subject to market transactions and therefore, economic valuation techniques are required to be used in order to determine a monetary measure of its value [19] by avoiding the idea of merchandizing them, but raising awareness in society to consider this value for decision making and a more sustainable resource control [9].

Worldwide, there are more than hundred economic valuation studies of environment goods and services offered by a wetland, focused on those goods and services mainly having a market value such as fishery [20]-[22], timber-yielding products [20], tourism [20] [21] [23]. However, there are less studies when dealing with goods and services that have no market value, such as carbon sequestration [22] [24], water adjustment [21] [22], biodiversity [24], bird and wild fauna appreciation [25] [26], erosion control [21], weather adjustment [21], flooding control [22] [27] [28], water quality improvement [29] [30], organic matter recycling [23], etc. Nevertheless, studies to be focused on economically estimating cultural values such as traditions, religious or spiritual aspects, knowledge transfer between generations, historical-value scenic beauty society are limited [11] [31] [32].

Basically, literature about scenic beauty valuation is focused on real estate market's price studies, related to any environment goods or services by means of hedonic prices technique [33]. For instance, Gillard [34] utilizes such technique to estimate the effect on an excellent sight of the place upon housing values on Los Angeles urban area. On the other hand, there are other studies estimating price increase on houses related to the proximity to any environment goods such as oceans, lakes, rivers, hills, natural parks or wetlands [35]-[40]. However, in some cases, resorting to hedonic prices may underrate the environment goods or services, when real estate market remains incomplete, informal or does not exist directly [41]. In this case, it may be useful to resort to other techniques such as contingent valuation (CV), except that there are not enough literature sources [32] [33] [42].

The urban wetland called Ejidos de Xochimilco and San Gregorio Atlapulco, which is located in Mexico City since pre-Hispanic times has been an important place for the country center, due to farm production by means of chinampas (raised beds) as a farming way to be considered unique worldwide [43] [44]. Such chinampas, which are built rectangular-shaped artificial isles based on water vegetation layers, are considered to be farm Middle American methods and territory extensions managed between XIV to XVI centuries; and because of their stateliness, they have been worldwide under consideration since Spanish conquerors discovered their existence in the XVI century [43] [44]. Besides having that cultural value, such wetland is very important in terms of biodiversity since it shelters a huge amount of flora and fauna species, both water and earth species, by providing an important genetic heritage and working as a feeding and fish and bird reproduction areas [45]. Because of this, the Ejidos de Xochimilco and San Gregorio Atlapulco wetland belongs to the UNESCO declaration as a Human, 
Natural and Cultural Heritage (1987), besides of being considered as a protected natural area (1992) and Ramsar site (2004). However, despite having such recognition and importance, the Xochimilco region has been threatened by many factors such as urban parades invasion, technified farming expansion, invader species introduction, lack of planning and insufficient comprehension about wetland's economic values, complicating its preservation and permanency [46] [47].

In such sense, it is necessary to perform an economic valuation on Xochimilco region's importance from a cultural viewpoint, especially due to scenic beauty offered by this pre-Hispanic farming activity to society. Therefore, this work tries to estimate the willingness-to-pay (WTP) of tourists in order to preserve the Ejidos de Xochimilco and San Gregorio Atlapulco Lake System's chinampa culture. We must stress that the study seeks to estimate the economic and cultural value that tourists have on the conservation of chinampas, and for that you are looking for an approximation, which in this case may be the construction of a hypothetical market of tourist attractions to visit the place as a cultural site. Then, the document goes on to Section 2, where methods are described, study field, sampling and analysis of considered variables are all showed; while results are showed in Section 3 and the ending part comprises both discussion and conclusion in Section 4.

\section{Methods}

Provided data in this work is raised from a survey application to tourists in order to analyze the willingness-topay (WTP), as a contribution to achieve the preservation of the Ejidos de Xochimilco and San Gregorio Atlapulco Lake System's canals and chinampas, by considering that these are highly productive pre-Hispanic farming systems and offer an economic, environment and culture benefits variety to the society such as a recreation place, flora and fauna presence, raised beds culture, etc. After applying surveys, a variable selection is performed in order to finally establish a logistic econometric model to estimate visitor's willingness-to-pay (WTP).

\subsection{Study Field}

The Ejidos de Xochimilco and San Gregorio Atlapulco Lake System is located in Mexico City's center-southeast region, Mexico, and shows a 2,657 hectare surface around [48] (Figure 1). Because of its proximity to the urban area, there is a strong pressure inside the site, so we can find irregular human settlements, and settled population in that lake system area is estimated to be 24,100 inhabitants while at the immediate influence area, there are 121,130 inhabitants [44] [48]. Likewise, as being declared a protected natural area, the lake system is located in the so-called conservation area, and comprises a remnant ecosystem of the Mexico Basin, which consists of natural flooded plains and induced water bodies [46] [49].

It shelters a huge amount of flora and fauna species, both water and earth species (Figure 2). There is a registration of 146 flora species and spreads in 101 genders and 45 families [48], while water vegetation is represented by 115 species and spreads in 63 genders. Concerning fauna species, it comprises 272 species: 21 fish, 6 amphibian, 10 reptiles, 23 mammals and 212 wild birds [48] [50]. Besides all of its natural richness, such lake system has a huge cultural due to raised beds farming's development dating from pre-Hispanic era [43]. The chinampas, or artificial isles built with logs, lake sediments and waste vegetation, were capable to produce the highest part of consumed food in the Tenochtitlan region, the Mexica Empire capital, founded in 1325 and conquered by Spaniards in 1521, under Mr. Hernan Cortes command [43]. Nowadays, such raised beds are recognized as highly productive traditional agro-ecosystems that continue providing vegetables and flowers to Mexico City and its surroundings by keeping the raised beds culture in preservation [44].

\subsection{Sampling and Survey}

A visitor-addressed survey was designed to both national and international tourists who are visiting or have visited the Ejidos de Xochimilco and San Gregorio Atlapulco Lake System during the last year. Hence, 810 surveys, 700 national surveys and 110 international surveys were performed (Table 1); and such surveys were applied from February to May 2014 by tourists groups in social networks such as in different wharfs of that lake system. Before applying the final survey, a pilot test was performed from November to December 2013, in order to check if questions were correctly asked and enquire about the rank the question may have about willingness-topay. 


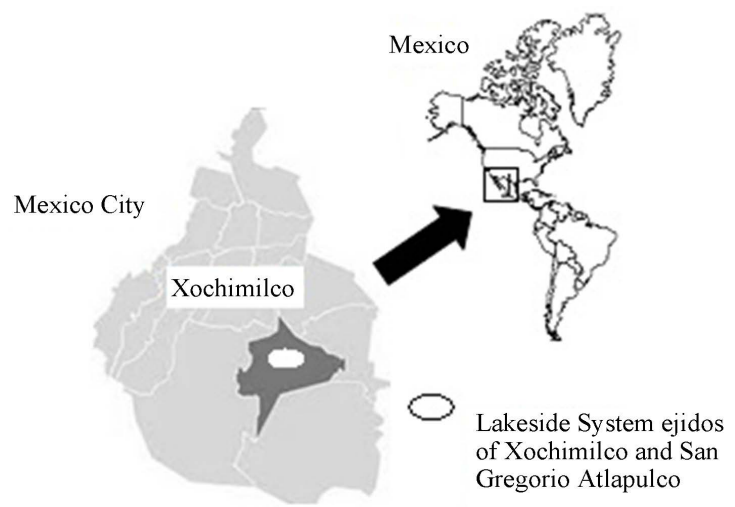

Figure 1. Lakeside system ejidos of Xochimilco and San Gregorio Atlapulco, Mexico.

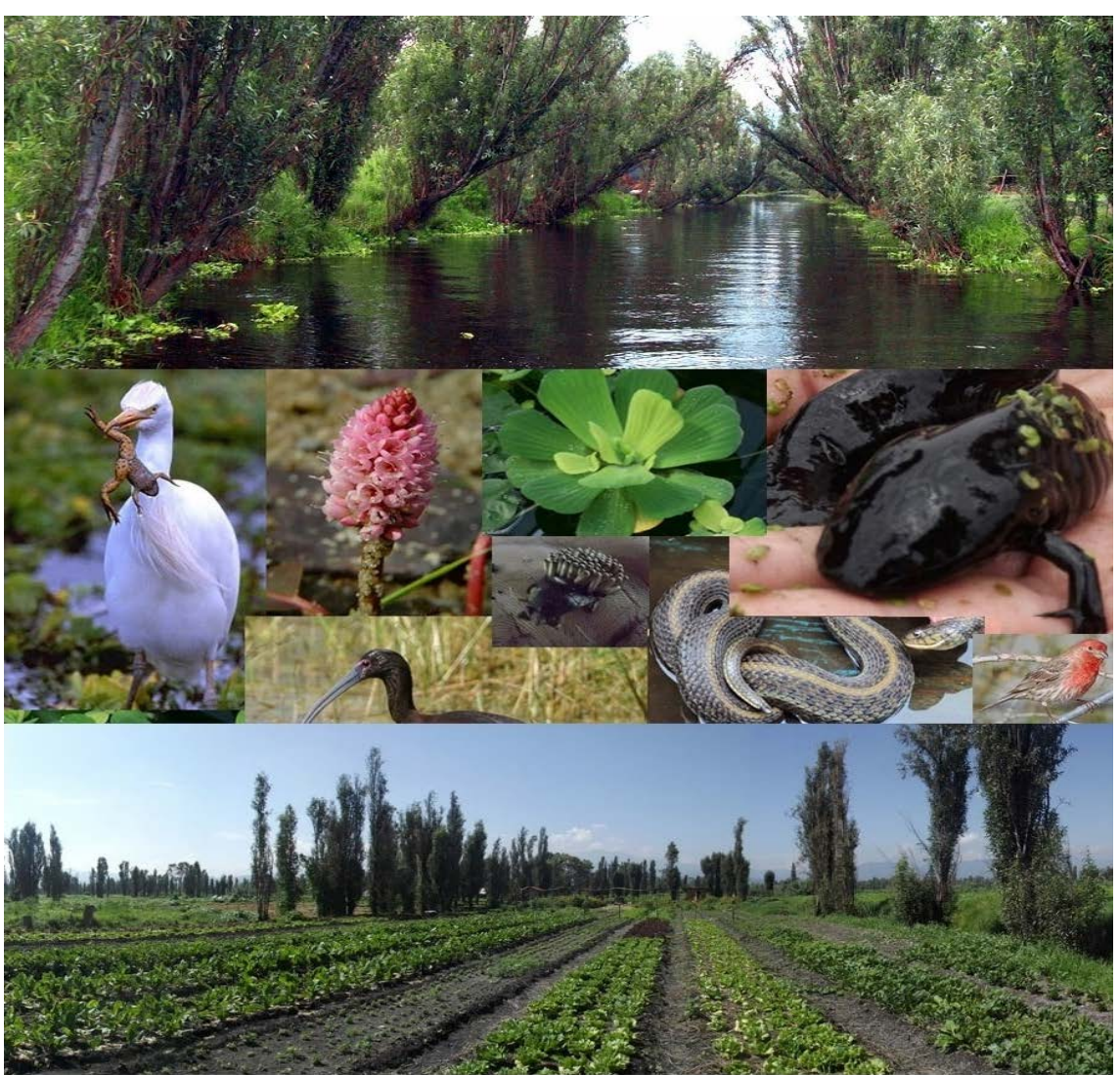

Figure 2. Biodiversity and landscape (chinampas)—Ejidos de Xochimilco and San Gregorio Atlapulco, Mexico.

Table 1. Sample number considered for the study.

$\begin{array}{ccc}\text { National } & 700 & 86.40 \% \\ \text { International } & 110 & 13.60 \% \\ \text { TOTAL } & 810^{*} & 100 \%\end{array}$

${ }^{*}$ In 2012, according to the Mexico City Secretariat of Tourism, and from more than 12.5 million tourists visiting Mexico City annually, a million 200 thousand people, either domestic and foreigners, visit the Xochimilco region, so in that sense, by considering this amount of tourists who arrive to the Xochimilco region, and by considering both a secondary mistake of $5 \%$ and a reliability level of $95 \%$, the final sampling must raise from 385 surveys at least. The secondary mistake, however, is reduced to $3.4 \%$ with a reliability level of $99.6 \%$, when performing 810 surveys. 
The final survey is divided in three sections. The first one comprises questions about general aspects when visiting the site, the second one comprises an explanation about the Ejidos de Xochimilco and San Gregorio Atlapulco Lake System and its economic, environment and culture relevance mainly, in order to enquire the survey respondent about his/her willingness-to-pay for the raised beds culture's preservation. Finally, the third section comprises the searching of interviewed people's socio-economic aspects.

\subsection{Variable Selection}

By means of applied surveys, thirty variables were obtained approximately, from which a selection to estimate both the econometric model and statistical analysis was performed. Concerning the econometric model, it is considered as a dependent dichotomous variable if the tourist is willing or not to pay certain money amount per year, in order to preserve canals and chinampas from the Ejidos de Xochimilco and San Gregorio Atlapulco Lake System, by considering that these are highly productive pre-Hispanic farming systems and they provide economic and environment benefits variety to the society such as recreation place, fauna and flora presence, raised beds culture, etc.

In the case of the independent variables, two criteria were selected as a basis:

1) Statistical: it was verified that the econometric model had no multicollinearity and heteroskedasticity problems. In the case of multicollinearity, it was resorted to the measure of Inflation Variance Factor (IVF); while in the case of heteroskedasticity, the Breusch-Pagan Test was used;

2) Socioeconomic: it considered other studies where scenic beauty is analyzed and detected economic, social and/or environmental variables that may be important in the analysis of this activity.

The variables selected to explain the dependent variable are in Table 2.

\subsection{Model Description}

An utility function is determined to the tourist if saying no to the WTP question related to the preservation of the Ejidos de Xochimilco and San Gregorio Atlapulco Lake System's canals and chinampas $\left(U_{0}\right)$; and there is another one if saying yes $\left(U_{1}\right)$. Utility function if saying that is not represented as:

$$
U_{o}(Y, S)
$$

where $Y$ is the income of the respondent and $S$ are other individual characteristics such as age, sex, number of children, among other variables. The utility function if the individual responds yes to the payment is represented as:

$$
U_{1}(Y-P, S)
$$

where $P$ is the amount of money the respondent has to pay to keep Xochimilco. This method is based on the following assumptions:

- The utility has two components, one unobservable (random) and a deterministic that can be controlled.

- The probability that the individual will answer yes is:

$$
\operatorname{Prob}(\text { Say Yes })=\operatorname{Prob}\left(U_{1}>U_{0}\right)
$$

- A linear utility function is assumed with respect to income, and the rest from other characteristics of the respondent, this implies that there is no income effect. Then:

$$
U_{0}(Y, S)=\alpha_{00}+\alpha_{01} S+\beta Y+\epsilon_{0}
$$

where $\alpha_{00}+\alpha_{01} S+\beta Y$ is the deterministic component of the utility function and $\epsilon_{0}$ is the random component with an $E\left(\epsilon_{0}\right)=0$. And the utility function with change defined as:

$$
U_{1}(Y-P, S)=\alpha_{00}+\alpha_{01} S+\beta(Y-P)+\epsilon_{1}
$$

As mentioned above, the probability of saying yes to the payment is given by:

$$
\begin{gathered}
\operatorname{Prob}(\text { Say Yes })=\operatorname{Prob}\left(U_{1}>U_{0}\right) \\
U_{1}(Y-P, S)-U_{0}(Y, S)=\left(\alpha_{00}+\alpha_{01} S+\beta(Y-P)+\epsilon_{1}\right)-\left(\alpha_{00}+\alpha_{01} S+\beta Y+\epsilon_{0}\right)
\end{gathered}
$$


Table 2. Selected variables to be included in the model explained by the WTP in order to preserve the Ejidos de Xochimilco and San Gregorio Atlapulco Lake System’s canals and chinampas.

\begin{tabular}{|c|c|c|}
\hline Model & Reply tourists associated with the variable & Prognostic \\
\hline \multicolumn{3}{|c|}{ Dependent variable } \\
\hline $\mathrm{WTP}^{\dagger}$ & $\begin{array}{l}\text { What would be the maximum amount of money you would pay as a contribution to achieving conservation } \\
\text { of canals and chinampas of Lakeside System ejidos of Xochimilco and San Gregorio Atlapulco, considering } \\
\text { that these are highly productive prehispanic agricultural systems and offer a variety of economic, } \\
\text { environmental and cultural benefits primarily? Would you pay the amount of US\$ "X" per year?" }\end{array}$ & \\
\hline \multicolumn{3}{|c|}{ Independent variable } \\
\hline \multicolumn{3}{|c|}{ Group: Socio-Economic } \\
\hline $\operatorname{Age}^{y}$ & Number of years the tourist. &,+- \\
\hline Gender $^{\dagger}$ & $1=$ Man y 0 = Woman. &,+- \\
\hline Income $^{\varnothing}$ & $\begin{array}{l}\text { Range where the income is located. } \\
31 \text { ranges available, where they go from lowest to highest value. }\end{array}$ & + \\
\hline Children $^{*}$ & Number of children of the tourist. & - \\
\hline \multicolumn{3}{|c|}{ Group: Qualitative Place } \\
\hline Landscape $^{\dagger}$ & Tourists will enjoy the landscape: $Y e s=1$, No $=0$. & + \\
\hline Protection $^{ø}$ & $\begin{array}{l}\text { Consider that the protection of Xochimilco is } \\
1 \text { = nothing important, } 2 \text { = moderately important, } 3 \text { = very important. }\end{array}$ & + \\
\hline $\mathrm{Buy}^{\dagger}$ & Tourists want to buy agro products: Yes $=1$, No $=0$. & + \\
\hline \multicolumn{3}{|c|}{ Group: Management Xochimilco } \\
\hline Posture $^{y}$ & WTP posture that offers tourists to its decision. & - \\
\hline $\mathrm{CSO}^{\dagger}$ & $\begin{array}{l}\text { The conservation and management of money should be performed by: } \\
\text { Civil Society Organization: Yes }=1 \text {, No }=0 \text {. }\end{array}$ &,+- \\
\hline $\mathrm{PGE}^{\dagger}$ & $\begin{array}{l}\text { The conservation and management of money should be performed by: } \\
\text { Public and/or Government Entity: Yes }=1, \text { No }=0 \text {. }\end{array}$ &,+- \\
\hline
\end{tabular}

* 18 values between 4.5 and 57.5 dollars were generated, and they were showed randomly among survey respondents and were the result on pilot survey; ${ }^{\dagger}$ Dichotomous variables: Yes (1), No (0); ${ }^{\vee}$ Continuous variables; ${ }^{\varnothing}$ Categorical variables.

$$
U_{1}(Y-P, S)-U_{0}(Y, S)=\left(\alpha_{10}-\alpha_{00}\right)+\left(\alpha_{11}-\alpha_{01}\right) S-\beta P+\left(\epsilon_{1}-\epsilon_{0}\right)
$$

Yes: $\alpha_{0}=\alpha_{10}-\alpha_{00}, \alpha_{1}=\alpha_{11}-\alpha_{01} \quad y \in=\epsilon_{1}-\epsilon_{0}$, then:

$$
\operatorname{Prob}(\text { Say Yes })=\operatorname{Prob}\left(\alpha_{0}-\alpha_{1} S-\beta P>\epsilon\right)
$$

where in the term $\in$ represents model errors distributed logistically, therefore:

$$
\operatorname{Prob}(\text { Say Yes })=\operatorname{Prob}\left(\alpha_{0}-\alpha_{1} S-\beta P>\epsilon\right)=1 /\left[1+e^{-(\alpha-\beta P)}\right]
$$

To find the maximum willingness-to-pay (WTP), it is needed to:

$$
\alpha_{10}+\alpha_{11} S+\beta(Y-W T P)+\epsilon_{1}=\alpha_{00}+\alpha_{01} S+\beta Y+\epsilon_{0}
$$

Therefore, the expected value of the WTP will be given by:

$$
\begin{gathered}
E(W T P)=E\left[\left(\alpha_{0}+\alpha_{1} S\right) / \beta\right]+E[\in / \beta] \\
E(W T P)=\left(\alpha_{0}+\alpha_{1} S\right) / \beta
\end{gathered}
$$

In this sense, a logit model is performed since the dependent variable has only two values: if the tourist is willing to pay or not certain money amount per year, as a contribution to preserve the Ejidos de Xochimilco and 
San Gregorio Atlapulco Lake System's canals and chinampas (WTP: YES $=1, \mathrm{NO}=0$ ).

$$
\begin{aligned}
& W T P=X_{0}+X_{1} * \text { AGE }+X_{2} * \text { GENDER }+X_{3} * \text { INCOME }+X_{4} * \text { CHILDREN }+X_{5} * \text { LANDSCAPE } \\
& +X_{6} * \text { PROTECTION }+X_{7} * \text { BUY }+X_{8} * \text { POSTURE }+X_{9} * \mathrm{CSO}+X_{10} * \text { PGE }+\epsilon
\end{aligned}
$$

\section{Results}

Descriptive statistics to visitors show that $62 \%$ of survey respondents have said yes to the value or position that was shown as a possible contribution to preserve the Ejidos de Xochimilco and San Gregorio Atlapulco Lake System's canals and raised beds (Table 3). When analyzing variables by groups in the case of socio-economic variables, it is noted that survey respondents are between 34 and 35 years old on average, $42 \%$ are men, average income is 850 dollars per month (US\$ on 2014) and each visitor has one child approximately. Regarding variables comprising the Place's Quality Group, it is identified that $81 \%$ points out that tourists go there in order to enjoy the landscape; and averagely visitors point out that preservation of Xochimilco regions is very important, whereas $98 \%$ would be willing to buy agro-ecologic products such as vegetables and/or flowers grown at the raised beds by locals. Concerning the Xochimilco Management Group’s variables, 68\% of survey respondents point out that both the preservation program and the monetary funds for this activity must be handled by a civil society's organization, whereas $14 \%$ of survey respondents point out that it should be handled by a government's and/or independent public entity.

In general terms, the estimated econometric model shows statistical relevance to a level of $1 \%$ (Prob $>\mathrm{Xi}^{2}=$ 0.0001 ) (Table 4). Approximately, $70 \%$ of considered variables are statistically important to $10 \%$ at least; but it is necessary to consider that even unimportant variables do not stop of being economically important. Independent variables' symbols shown in Table 2 are the expected ones. Concerning the Socio-Economic Group variables, the results point out that: 1) as the tourist has one more year of life, the probability of saying yes to the payment increases to $0.2 \%$; 2 ) if the tourist is a woman, the probability of willingness-to-pay increases to $5 \%$; 3 ) for each increase additional rank on economic income, the probability to pay for preservation of canals and raised beds in Xochimilco region increase to $0.4 \%$; and finally 4 ) for each additional visitor's child, the probability to pay decreases to $6.8 \%$.

The Place’s Quality Group's variables show the second biggest average contribution by variables in order to explain dependent variables. For each variable comprised by this group, it is noted that: 1 ) if the tourist wants to enjoy the landscape or scenic beauty of the Ejidos de Xochimilco and San Gregorio Atlapulco Lake System's

Table 3. Descriptive statistics of the variables considered in the study.

\begin{tabular}{cccccc}
\hline & $\mathrm{N}$ & Mean & S.D. & Min & Max \\
\hline WTP & 810 & 0.62 & 0.49 & 0 & 1 \\
Age & 810 & 34.54 & 12.31 & 17 & 83 \\
Gender & 810 & 0.42 & 0.49 & 0 & 1 \\
Income & 810 & 12.36 & 8.26 & 1 & 31 \\
Children & 810 & 0.77 & 1.11 & 0 & 10 \\
& & Group: Socio-Economic & & \\
Landscape & 810 & 0.81 & 0.46 & 0 & 1 \\
Protection & 810 & 2.83 & 0.39 & 1 & 3 \\
Buy & 810 & 0.98 & 0.11 & 0 & 1 \\
& & Group: Management Xochimilco & & 1 \\
Posture & 810 & 30.94 & 16.46 & 4.5 & 57.5 \\
CSO & 810 & 0.68 & 0.47 & 0 & 1 \\
PGE & 810 & 0.14 & 0.35 & 0 & 1 \\
\hline
\end{tabular}




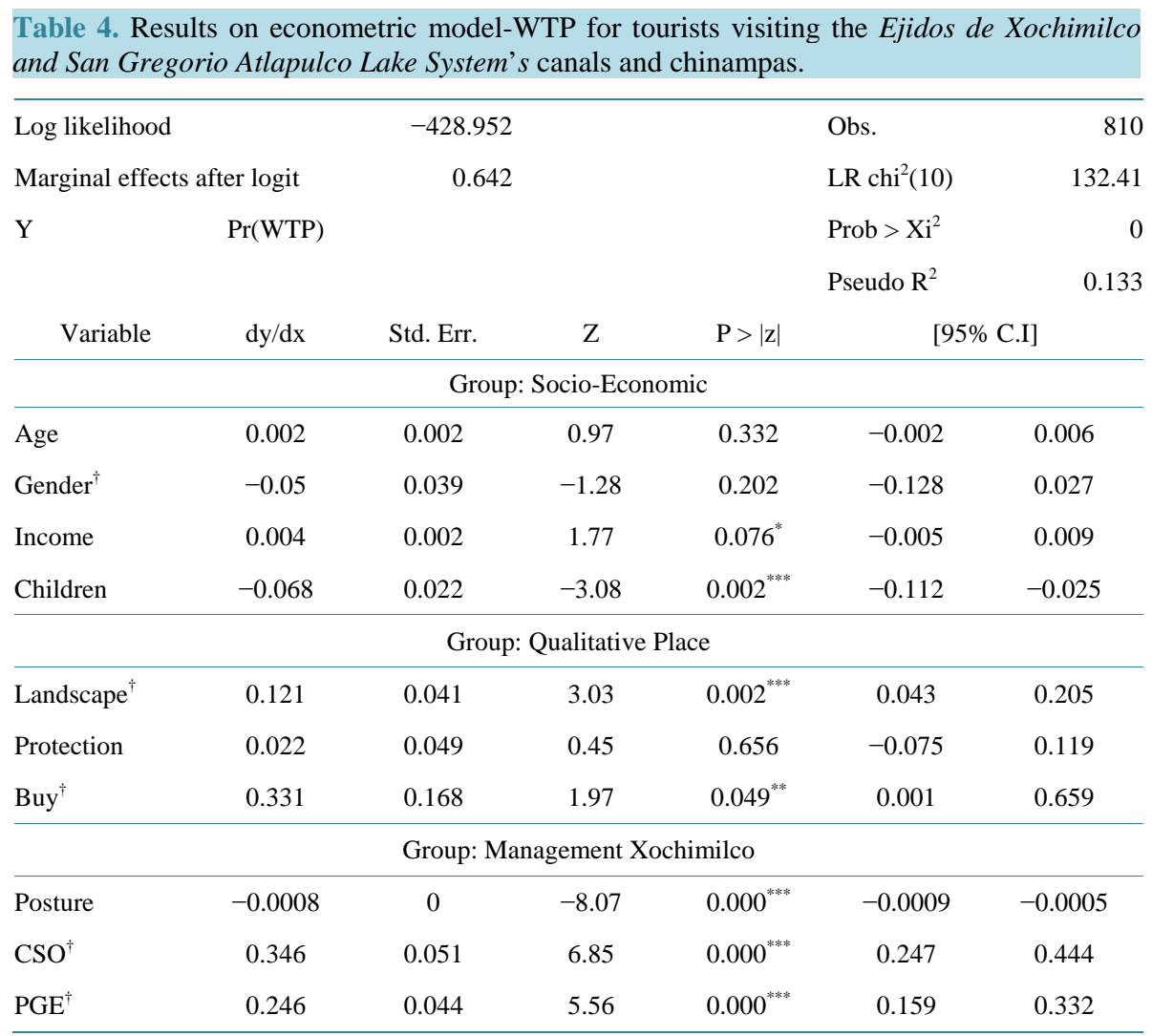

${ }^{\dagger} \mathrm{dy} / \mathrm{d}$ xis for discrete change of the dummy variable from o to 1 . Significant at $1 \%\left({ }^{* * *}\right), 5 \%\left({ }^{* *}\right)$ y $10 \%\left({ }^{*}\right)$.

canals and raised beds, the probability increases to $12 \%$ that such visitor is willing to make a contribution for preservation; 2) as the tourist shows that it is more important to preserve such canals and raised beds, such probability increases then in 2.2\%; and 3) if the visitor wants to buy agro-ecologic products grown at the raised beds by locals, the probability to make a contribution or payment to preserve such raised beds increases to 33\%.

Regarding the Xochimilco Management Group's variables, it is noted that: 1) as the amount or position faced by the survey respondent to decide if he/she pays or not for the preservation of canals and raised beds increases, the probability of acceptation is reduced to $0.01 \%$; 2 ) if visitors are certain about the preservation program to be managed and coordinated by a civil society's organization, from both activity and economic viewpoints, then the probability to accept the WTP increases to $34.6 \%$; and 3) if such activities are managed by a public institution, such probability would be $24.6 \%$.

Finally, such found effects for suggested econometric model allow the estimation of tourist's annual willingness-to-pay (WTP) in order to preserve the Ejidos de Xochimilco and San Gregorio Atlapulco Lake System's canals and raised beds as an historical scenic beauty. When replacing these effects on 13 equation, it is estimated that the annual WTP per tourist is equal to 24.4 dollars approximately (US\$ in 2014).

\section{Discussion and Conclusions}

Besides providing supply services (such as food, water, wood, genetic materials), adjustment (such as weather, water cycle, water purification and erosion) and support (such as ground formation and nutriments cycle), wetlands also provide important culture services such as spiritual, recreation, education, historical and aesthetical places [2]. The latter have the same importance as the rest [51], but they are not totally researched or valued from an economic viewpoint [52], since people do not perceive the monetary value provided by the scenic beauty mainly when considering it as a free environment service [9]. An example of this is the situation of the Ejido de Xochimilco and San Gregorio Atlapulco urban wetland, which is located in Mexico City, and which is also a Ramsar place or protected natural area and classified as Human, Natural and Culture Heritage by the UNESCO due to raised beds presence; since it is suffering from a constant pressure due to urban parades in- 
crease, chemical polluting agents from farming product greenhouses, irregular human settlements, direct unloading of domestic waste, etc. Therefore, it is really important to have an environment goods and services' economic value approximation provided by his Human Heritage, in order to show biologic, economic and cultural importance related to the preservation of this kind of place to develop the future public policies for society's benefit.

In that sense, the willingness-to-pay (WTP) estimation of visitors to such wetland, in order to preserve canals and raised beds from a historical scenic beauty viewpoint, is important since trying to quantify the value that people do have or feel for it in monetary terms. Approximately, such WTP is equal to 24.4 dollars annually, and allows estimating that the economic value for the scenic beauty service from the whole society is located between 8 and 9.8 annual million dollars (US\$ in 2014) (Table 5). Such estimation, 3 thousand to 3 thousand and seven hundred US\$/hectare, allows having a partial approximation of an environment service's economic value provided by the Xochimilco region to the Mexico City inhabitants, and can be used as a tool to discuss with authorities and/or public policy makers about the future of this urban wetland [17] [18]. It is useful to public policy developers, on the other hand, to know that different treated environment goods or services' socio-economic and/or quality variables may impact, in a good or bad way, the decision to accept or not willingness-to-pay by visitors, and therefore the future of a certain project or policy [17]. Concerning socio-economic variables, aging shows a positive relationship regarding the probability to say yes to the WTP as indicated by Loomis \& González-Caban [53] and Ojea \& Loureiro [26]. In other words, the older, the bigger the probability that visitors are willing to pay would be in order to preserve canals and raised beds. Just like Kaffashi et al. [54], a direct relationship is showed between the WTP and the income; or the higher income levels, the higher probabilities to accept a payment would be. Such variable behaves according to statements on economic theory, especially when determining the demand for a common goods. Finally, within considered variables belonging to the Socio-EcoNomic Group, children's sex and number have the highest weight or impact regarding acceptance or not of one WTP. Women instead, have a higher probability to accept the payment so as to reach the preservation of Xochimilco region, as it happens with Choong-Ki et al. [55] and El-Bekkay, Moukrim \& Benchakroun's [56] works. According to studies on gender and natural resources, this can be explained since women have a bigger vocation or a higher instinct to reach the preservation of resources regarding men, in order to leave something for the future, either for consumption or enjoyment of this or following generations [57] [58].

Table 5. WTP's awareness analysis of tourists to the Ejido de Xochimilco and San Gregorio Atlapulco urban wetland.

\begin{tabular}{|cccc}
\hline & Tourists & $1,200,000$ & Per annum ${ }^{*}$ \\
\hline$\%{ }^{* *}$ & $\mathrm{~N}^{\circ}$ & US\$ & US\$/Hect. \\
\hline $1.00 \%$ & 12,000 & $\$ 292,800$ & $\$ 110$ \\
$5.00 \%$ & 60,000 & $\$ 1,464,000$ & $\$ 551$ \\
$10.00 \%$ & 120,000 & $\$ 2,928,000$ & $\$ 1102$ \\
$15.00 \%$ & 180,000 & $\$ 4,392,000$ & $\$ 1653$ \\
$20.00 \%$ & 240,000 & $\$ 5,856,000$ & $\$ 2204$ \\
$25.00 \%$ & 300,000 & $\$ 7,320,000$ & $\$ 2755$ \\
$30.00 \%$ & 360,000 & $\$ 8,784,000$ & $\$ 3306$ \\
$40.00 \%$ & 480,000 & $\$ 11,712,000$ & $\$ 4408$ \\
$50.00 \%$ & 600,000 & $\$ 14,640,000$ & $\$ 5510$ \\
$60.00 \%$ & 720,000 & $\$ 17,568,000$ & $\$ 6612$ \\
LOWER-SB (10\%) & $\$ 8,037,360$ & $\$ 3025$ \\
SB scenic beauty (Average up 60\%) & $\$ 8,930,400$ & $\$ 3361$ \\
\multicolumn{2}{c}{ UPPER-SB (10\%) } & $\$ 9,823,440$ & $\$ 3697$ \\
\hline
\end{tabular}

*According to the Mexico City Secretariat of Tourism, in 2012 one million 200 thousand people visited the Xochimilco region. ${ }^{* * *}$ Tourists percentage that would pay a contribution in order to preserve the Xochimilco region's canals and raised beds as an historical scenic beauty place. 
Concerning the second group to be considered in this study the place's features, the variable that has a higher impact regarding the WTP would be if the visitor wants to buy or not agro-ecological products grown with raised beds culture's traditional ways. In this case, there is a direct relationship, so it is understood that if visitors notice that culture services provide them with satisfaction, they will be willing to make a contribution for its preservation [59]. In this sense, authorities should promote and/or support those farmers who perform their activities traditionally, or equivalent to this, by improving peoples' welfare and preserving the place. The other important variable is the purpose for which the visitor goes there, and in this case, if the purpose is related to enjoy such place's historical scenic beauty, more probabilities will raise to make a contribution for its preservation. And then, as suggested by Tahvanainen et al. [51], both the scenic beauty and recreation value are becoming more important, whereas its preservation is becoming more and more important for society's benefit.

The importance of the study's third variable group shows who must be in charge of both Xochimilco region's economic management and preservation program. In this case, the fact that a civil society's organization develops both activities would provide higher probabilities for visitors to make a contribution in order to preserve this Human Heritage, in comparison with a public and/or government institution. However, wetlands and Human, Natural and Cultural Heritage named by the UNESCO are considered to be public goods, so generally it is necessary to consider the development of mixed diagrams for its management.

It is important to show society that this kind of urban wetlands are not public space areas and they do not provide any kind of benefit to society; on the contrary, it must be showed and raised awareness that these spaces provide limited environment, economic and culture goods and services for the benefit of all of us. And if they have no market does not mean they have no value, and therefore they must not be preserved or less considered within the public policies' planning and development [60] [61]. Finally, we encourage other researchers and/or public policy developers to use this tool for environmental economic valuation to try to quantitatively demonstrate the importance of historical, cultural or environmental sites.

\section{Acknowledgements}

Thanks to Dr. Margarita Velázquez Gutierrez, director of Centro Regional de Investigaciones Multidisciplinarias (CRIM-UNAM) and all the staffs of that institution for their logistical support. Similarly, thanks to Raul Garcia Barrios and Alonso Aguilar Ibarra for academic advice, to Elsa Valiente, Citlalli Alhelí Gonzalez and all the staffs of Restauración Ecológica y Desarrollo A.C. for their support on the field, and especially to everyone who offered few minutes of your time to complete the surveys.

\section{References}

[1] Ramsar Convention Bureau (2014) http://www.ramsar.org/about-the-ramsar-convention

[2] Millennium Ecosystem Assessment (2005) Ecosystem Assessment, 2005. Ecosystems and Human Well-Being: Wetlands and Water Synthesis. World Resources Institute, Washington DC.

[3] Mitsch, W. and Gosselink, J.G. (2000) The Value of Wetlands: Importance of Scale and Landscape Setting. Ecological Economics, 35, 25-33. http://dx.doi.org/10.1016/S0921-8009(00)00165-8

[4] Benyamine, M., Bäckström, M. and Sandén, P. (2004) Multi-Objective Environmental Management in Constructed Wetlands. Environmental Monitoring and Assessment, 90, 171-185. http://dx.doi.org/10.1023/B:EMAS.0000003577.22824.8e

[5] Knight, R.L. (1997) Wildlife Habitat and Public Use Benefits of Treatment Wetlands. Water Science and Technology, 35, 35-43. http://dx.doi.org/10.1016/S0273-1223(97)00050-4

[6] Knight, R.L., Clarke Jr., R.A. and Bastian, R.K. (2001) Surface Flow (SF) Treatment Wetlands as a Habitat for Wildlife and Humans. Water Science and Technology, 44, 27-37.

[7] Barbier, E.B., Acreman, M. and Knowler, D. (1997) Economic Valuation of Wetlands-A Guide for Policy Makers and Planners. Ramsar Convention Bureau, Gland.

[8] Barbier, E.B. (1993) Sustainable Use of Wetlands Valuing Tropical Wetland Benefits: Economic Methodologies and Applications. The Geographical Journal, 159, 22-32. http://dx.doi.org/10.2307/3451486

[9] Biénabe, E. and Hearne, R. (2006) Public Preferences for Biodiversity Conservation and Scenic Beauty within a Framework of Environmental Services Payment. Forest Policy and Economics, 9, 335-348. http://dx.doi.org/10.1016/j.forpol.2005.10.002

[10] Campos, P., Caparrós, A. and Oviedo, J. (2007) Comparing Payment-Vehicule Effect in Contingent Valuation Studies 
for Recreational Use in Two Protected Spanish Forests. Journal of Leisure Research, 39, 60-85.

[11] Schuyt, K. and Brander, L. (2004) The Economic Values of the World's Wetlands. World Wide Fund (WWF), Gland/ Amsterdam. http://d2ouvy59p0dg6k.cloudfront.net/downloads/wetlandsbrochurefinal.pdf

[12] Turner, R.K., van den Bergh, J.C.M., Soderqvist, T., Barendregt, A., van der Straaten, J., Maltby, E. and van Ierland, E.C. (2000) Ecological-Economic Analysis of Wetlands: Scientific Integration for Management and Policy. Ecological Economics, 35, 7-23. http://dx.doi.org/10.1016/S0921-8009(00)00164-6

[13] Landgrave, R. and Moreno-Casasola, P. (2012) Evaluación cuantitativa de la pérdida de humedales en México. Investigación Ambiental, 4, 19-35.

[14] Torell, M., Salamanca, A.M. and Ahmed, M. (2001) Management of Wetland Resources in the Lower Mekong Basin: Issues and Future Directions. Naga, 24, 4-10.

[15] de Groot, R.S., van der Perk, J.P., Chiesura, A. and van Vliet, A.J.H. (2003) Importance and Threat as Determining Factors for Criticality of Natural Capital. Ecological Economics, 44, 187-204. http://dx.doi.org/10.1016/S0921-8009(02)00273-2

[16] Scodari, P.F. (1990) Wetlands Protection: The Role of Economics. Environmental Law Institute Monograph, Washington DC.

[17] Moran, D., Laycock, H. and While, P.C.L. (2010) The Role of Cost-Effectiveness Analysis in Conservation Decisionmaking. Biological Conservation, 143, 826-827. http://dx.doi.org/10.1016/j.biocon.2009.12.007

[18] Lu, H.F., Campbell, D., Chen, J., Qin, P. and Ren, H. (2007) Conservation and Economic Viability of Nature Reserves: An Emergy Evaluation of the Yancheng Biosphere Reserve. Biological Conservation, 139, 415-438. http://dx.doi.org/10.1016/j.biocon.2007.07.014

[19] Woodward, R. and Wui, Y.S. (2001) The Economic Value of Wetland Services: A Meta-Analysis. Ecological Economics, 37, 257-270. http://dx.doi.org/10.1016/S0921-8009(00)00276-7

[20] Schuijt, K.D. and Jansen, J. (1999) Economic Valuation of the Lake Chilwa Wetland. Report for the Lake Chilwa Wetland and Catchment Management Project, Danida.

[21] Seidl, A.F. and Moraes, A.S. (2000) Global Valuation of Ecosystem Services: Application to the Pantanal da Nhecolandia, Brazil. Ecological Economics, 33, 1-6. http://dx.doi.org/10.1016/S0921-8009(99)00146-9

[22] Emerton, L. and Kekulandala, L.D.C.B. (2003) Assessment of the Economic Value of Muthurajawela Wetland. Occasional Papers of IUCN Sri Lanka No.4.

[23] de Groot, R.S. (1992) Functions of Nature: Evaluation of Nature in Environmental Planning, Management and Decision Making. Wolters-Noordhoff, Groningen.

[24] Aguilar, A., Zambrano, L., Valiente, E. and Ramos-Bueno, A. (2012) Enhancing the Potential Value of Environmental Services in Urban Wetlands: An Agro-Ecosystem Approach. Cities, 31, 438-443.

[25] Brouwer, R., van Beukering, P. and Sultanian, E. (2008) The Impact of the Bird Flu on Public Willingness to Pay for the Protection of Migratory Birds. Ecological Economics, 64, 575-585. http://dx.doi.org/10.1016/j.ecolecon.2007.04.001

[26] Ojea, E. and Loureiro, M.L. (2007) Altruistic, Egoistic and Biospheric Values in Willingness to Pay (WTP) for Wildlife. Ecological Economics, 63, 807-814. http://dx.doi.org/10.1016/j.ecolecon.2007.02.003

[27] Kirkland, W.T. (1988) Preserving the Whangamarino Wetland-An Application of the Contingent Valuation Method. Master's Thesis, Massey University, Wellington.

[28] Thibodeau, F.R. and Ostro, B.D. (1981) An Economic Analysis of Wetland Protection. Journal of Environmental Management, 12, 19-30.

[29] Bystrom, O. (2000) The Replacement Value of Wetlands in Sweden. Environmental Resources Economics, 16, 347362. http://dx.doi.org/10.1023/A:1008316619355

[30] Dehnhardt, A. and Brauer, I. (2008) The Value of Floodplains as Nutrient Sinks: Two Applications of the Replacement Cost Approach. In: Burkhard, S.K., Ed., Ecosystem Services of Natural and Semi-Natural Ecosystems and Ecologically Sound Land Use, German Federal Agency for Nature Conservation, Bonn, 9-20.

[31] Hansen, T.B. (1997) The Willingness-to-Pay for the Royal Theatre in Copenhagen as a Public Good. Journal of Cultural Economics, 21, 1-28. http://dx.doi.org/10.1023/A:1007303016798

[32] Armbrecht, J. (2014) Use Value of Cultural Experiences: A Comparison of Contingent Valuation and Travel Cost. Tourism Management, 42, 141-148. http://dx.doi.org/10.1016/j.tourman.2013.11.010

[33] Ambrey, C.L. and Fleming, C.M. (2011) Valuing Scenic Amenity Using Life Satisfaction Data. Ecological Economics, 72, 106-115. http://dx.doi.org/10.1016/j.ecolecon.2011.09.011

[34] Gillard, Q. (1981) The Effect of Environmental Amenities on House Values: The Example of a View Lot. Professional 
Geographer, 33, 216-220. http://dx.doi.org/10.1111/j.0033-0124.1981.00216.x

[35] McLeod, P. (1984) The Demand for Local Amenity: A Hedonic Price Analysis. Environment and Planning A, 16, 389400. http://dx.doi.org/10.1068/a160389

[36] Benson, E., Hansen, J., Schwartz, A. and Smersh, G. (1998) Pricing Residential Amenities: The Value of a View. Journal of Real Estate Finance and Economics, 16, 55-73.

[37] Pearson, L., Tisdell, C. and Lisle, A. (2002) The Impact of Noosa National Park on Surrounding Property Values: An Application of the Hedonic Price Method. Economic Analysis and Policy, 32, 155-171. http://dx.doi.org/10.1016/S0313-5926(02)50023-0

[38] Jim, C. and Chen, W. (2009) Value of Scenic Views: Hedonic Assessment of Private Housing in Hong Kong. Landscape and Urban Planning, 91, 226-234. http://dx.doi.org/10.1016/j.landurbplan.2009.01.009

[39] Tapsuwan, S., Ingram, G., Burton, M. and Brennan, D. (2009) Capitalized Amenity Value of Urban Wetlands: A Hedonic Property Price Approach to Urban Wetlands in Perth, Western Australia. Australian Journal of Agricultural and Resources Economics, 53, 527-545. http://dx.doi.org/10.1111/j.1467-8489.2009.00464.x

[40] Samarasinghe, O. and Sharp, B. (2010) Flood and Happiness. Ecological Economics, 52, 111-125.

[41] Revollo-Fernandez, D. (2009) Calidad de la vivienda a partir de la metodología de precios hedónicos para la ciudad de Bogota-Colombia. Revista Digital Universitaria, 10. http://www.revista.unam.mx/vol.10/num7/art43/cita.htm

[42] Noonan, D.S. (2003) Contingent Valuation and Cultural Resources: A Meta-Analytic Review of the Literature. Journal of Cultural Economics, 27, 159-176. http://dx.doi.org/10.1023/A:1026371110799

[43] Rojas, T. (1995) Presente, pasado y futuro de las chinampas. CIESAS, Patronato del Parque Ecológico de Xochimilco, México.

[44] Merlin-Uribe, Y., Contreras-Hernández, A., Astier-Calderón, M., Jensen, O.P., Zaragoza, R. and Zambrano, L. (2013) Urban Expansion into a Protected Natural Area in Mexico City: Alternative Management Scenarios. Journal of Environmental Planning and Management, 56, 398-411. http://dx.doi.org/10.1080/09640568.2012.683686

[45] Valiente, E., Tovar, A., Gonzalez, H., Eslava-Sandoval, D. and Zambrano, L. (2010) Creating Refuges for the Axolotl (Ambystoma mexicanum). Ecological Restoration, 28, 257-259. http://dx.doi.org/10.3368/er.28.3.257

[46] Aguilar, A.G. (2008) Peri-Urbanization, Illegal Settlements and Environmental Impact in Mexico City. Cities, 25, 133145. http://dx.doi.org/10.1016/j.cities.2008.02.003

[47] Contreras, V., Martínez-Meyer, E., Valiente, E. and Zambrano, L. (2009) Recent Decline and Potential Distribution in the Last Remnant Area of the Microendemic Mexican Axolotl (Ambystoma mexicanum). Biological Conservation, 142, 2881-2885. http://dx.doi.org/10.1016/j.biocon.2009.07.008

[48] Gaceta Oficial del Distrito Federal (2006) Programa de Manejo del Área Natural Protegida con carácter de Zona de Conservación Ecológica “Ejidos de Xochimilco y San Gregorio Atlapulco”. Gaceta Oficial del Distrito Federal, Enero de 2006, 164.

[49] Wigle, J. (2010) The “Xochimilco Model” for Managing Irregular Settlements in Conservation Land in Mexico City. Cities, 27, 337-347. http://dx.doi.org/10.1016/j.cities.2010.04.003

[50] Hernández, C.A. and Meléndez, A.H. (1985) La riqueza de aves de Xochimilco. Universidad Autónoma Metropolitana. División Ciencias Biológicas y Salud, México, D.F.

[51] Tahvanainen, L., Tyrväinen, L., Ihalainen, M., Vuorela, N. and Kolehmainen, O. (2001) Forest Management and Public Perceptions-Visual versus Verbal Information. Landscape and Urban Planning, 53, 53-70. http://dx.doi.org/10.1016/S0169-2046(00)00137-7

[52] Flores, P.V., Martínez de Anguita, P., Romero, R.C., Novillo, C.J. and Ruiz, M.A. (2008) Los sistemas de pagos por servicios ambientales entre la adicionalidad y la subsidiariedad: aplicación a la belleza escénica en el pantano de San Juan, Madrid, España. Investigación Agraria: Sistemas y Recursos Forestales, 17, 39-53.

[53] Loomis, J.B. and González-Cabán, A. (1998) A Willingness-to-Pay Function for Protecting Acres of Spotted Owl Habitat from Fire. Ecological Economics, 25, 315-322. http://dx.doi.org/10.1016/S0921-8009(97)00044-X

[54] Kaffashi, S., Shamsudin, M.S., Radam, A., Yacob, M.R., Rahim, K.A. and Yazid, M. (2012) Economic Valuation and Conservation: Do People Vote for Better Preservation of Shadegan International Wetland? Biological Conservation, 150, 150-158. http://dx.doi.org/10.1016/j.biocon.2012.02.019

[55] Choong-ki, L., Jin-Hyung, L., Tae-Kyun, K. and Mjelde, J.W. (2010) Preferences and Willingness to Pay for BirdWatching Tour and Interpretative Services Using a Choice Experiment. Journal of Sustainable Tourism, 18, 695-708. http://dx.doi.org/10.1080/09669581003602333

[56] El-Bekkay, M., Moukrim, A. and Benchakroun, F. (2013) An Economic Assessment of the Ramsar Site of Massa (Morocco) with Travel Cost and Contingent Valuation Methods. African Journal of Environmental Science and Technology, 7, 441-447. 
[57] Nebasina, N. (1995) The Role of Women in Environmental Management: An Overview of the Rural Cameroonian Situation. GeoJournal, 35, 515-520. http://dx.doi.org/10.1007/BF00824366

[58] Agarwal, B. (2000) Conceptualising Environmental Collective Action: Why Gender Matters. Cambridge Journal of Economics, 24, 283-310. http://dx.doi.org/10.1093/cje/24.3.283

[59] de Groot, R., Finlayson, M., Verschuuren, B., Ypma, O. and Zylstra, M. (2008) Integrated Assessment of Wetland Services and Values as a Tool to Analyze Policy-Offs and Management Options: A Case Study in the Daly and Mary River Catchments, Northern Australia. Supervising Scientist Report 198, Supervising Scientist, Darwin NT.

[60] Ghermandi, A., van den Bergh, J.C.J.M., Brander, L.M., de Groot, H.L.F. and Nunes, P.A.L.D. (2010) Values of Natural and Human-Made Wetlands: A Meta-Analysis. Water Resources Research, 46, Article ID: W12516. http://dx.doi.org/10.1029/2010WR009071

[61] Stoll, J.R., Ditton, R.B. and Eubanks, T.L. (2006) Platte River Birding and the Spring Migration: Humans, Value, and Unique Ecological Resources. Human Dimensions of Wildlife, 11, 241-254.

http://dx.doi.org/10.1080/10871200600802939 